\title{
OSM wt Allele
}

National Cancer Institute

\section{Source}

National Cancer Institute. OSM wt Allele. NCI Thesaurus. Code C50956.

Human OSM wild-type allele is located in the vicinity of $22 q 12.2$ and is approximately $4 \mathrm{~kb}$ in length. This allele, which encodes oncostatin-M protein, is involved in both the regulation of cytokine production and proliferation. 